Prepared in cooperation with Green Oak and Hamburg Townships, Michigan and the U.S. Army Corps of Engineers

\title{
Hydraulic Modeling and Flood-Inundation Mapping for the Huron River and Ore Lake Tributary, Livingston County, Michigan
}

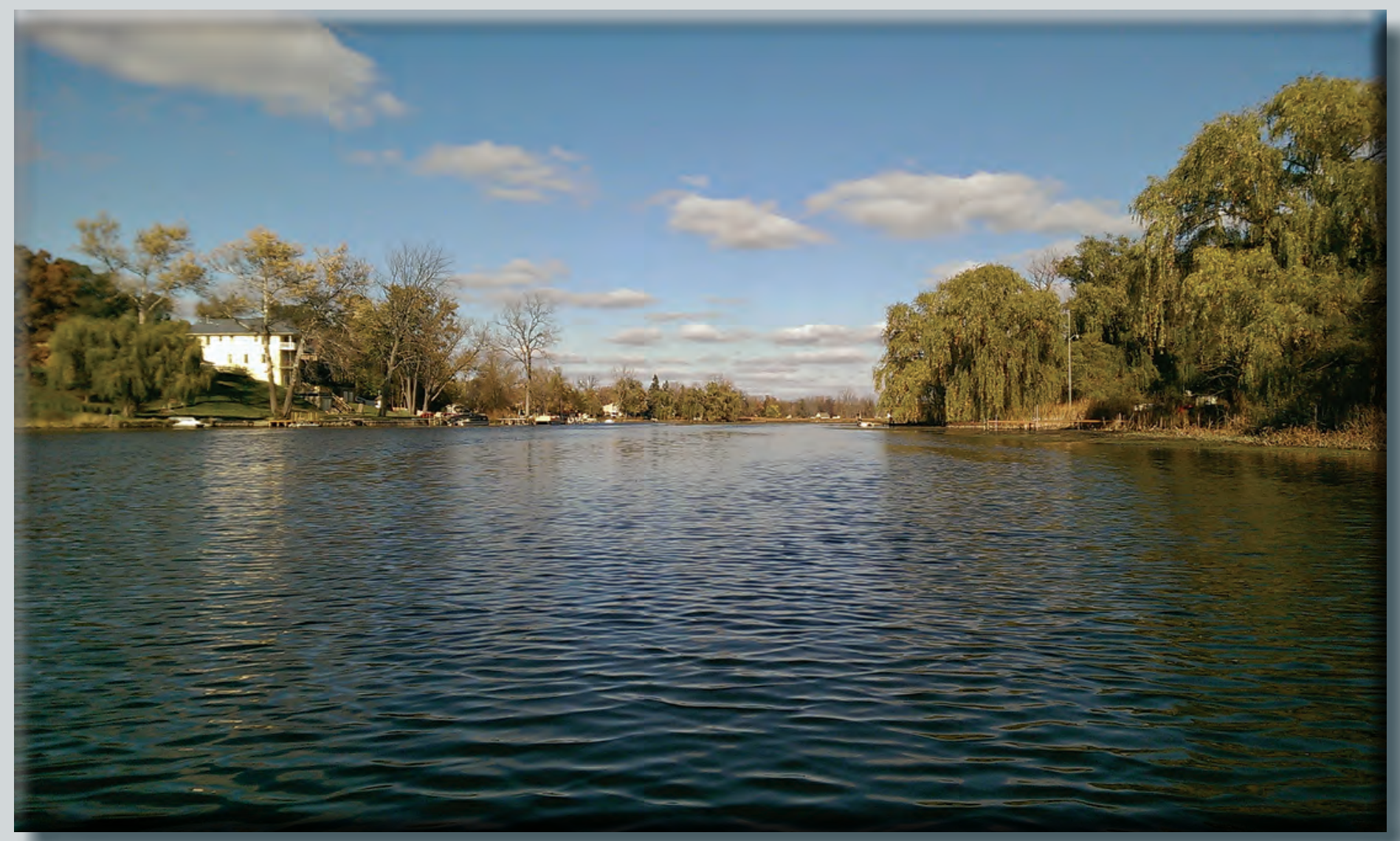

Scientific Investigations Report 2018-5048 
Front cover, Huron River near Hamburg, Michigan U.S. Geological Survey streamgage station number 04172000. Photograph by Julia Prokopec, September 2015. 


\section{Hydraulic Modeling and Flood-Inundation Mapping for the Huron River and Ore Lake Tributary, Livingston County, Michigan}

By Julia G. Prokopec

Prepared in cooperation with Green Oak and Hamburg Townships, Michigan and the U.S. Army Corps of Engineers

Scientific Investigations Report 2018-5048 


\section{U.S. Department of the Interior \\ RYAN K. ZINKE, Secretary}

\section{U.S. Geological Survey James F. Reilly II, Director}

\section{U.S. Geological Survey, Reston, Virginia: 2018}

For more information on the USGS - the Federal source for science about the Earth, its natural and living resources, natural hazards, and the environment-visit https://www.usgs.gov or call 1-888-ASK-USGS.

For an overview of USGS information products, including maps, imagery, and publications, visit https://www.usgs.gov/pubprod/.

Any use of trade, firm, or product names is for descriptive purposes only and does not imply endorsement by the U.S. Government.

Although this information product, for the most part, is in the public domain, it also may contain copyrighted materials as noted in the text. Permission to reproduce copyrighted items must be secured from the copyright owner.

Suggested citation:

Prokopec, J.G., 2018, Hydraulic modeling and flood-inundation mapping for the Huron River and Ore Lake Tributary, Livingston County, Michigan: U.S. Geological Survey Scientific Investigations Report 2018-5048, 13 p., https://doi. org/10.3133/sir20185048.

ISSN 2328-0328 (online) 


\section{Acknowledgments}

The author wishes to thank the many local, State, and Federal agencies that have cooperated in the funding for the operation and maintenance of the streamgages throughout the country. We especially thank Hamburg Township for their support of the streamgage referred to in this report. Special thanks go to Green Oak Township, Hamburg Township, and the U.S. Army Corps of Engineers for the support of this project. Special thanks also are given to the National Weather Service for their continued support of the U.S. Geological Society flood-inundation mapping program. 



\section{Contents}

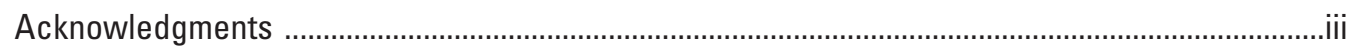

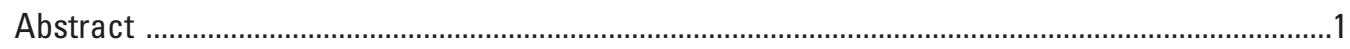

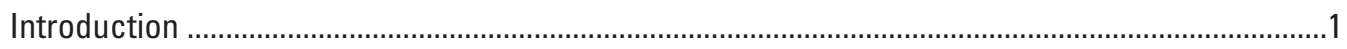

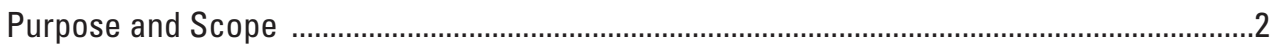

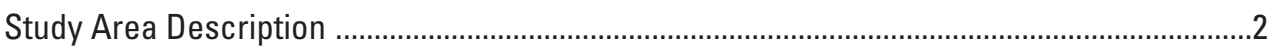

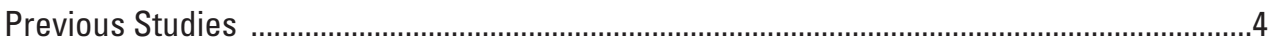

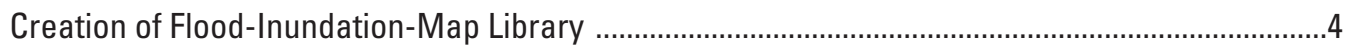

Computation of Water-Surface Profiles .............................................................................

Hydrologic Data .................................................................................................

Topographic and Bathymetric Data .........................................................................

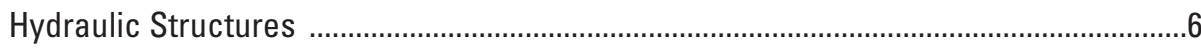

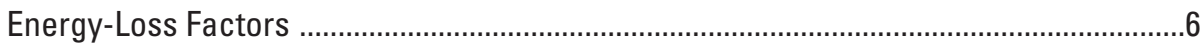

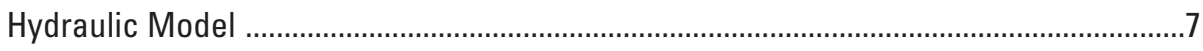

Model Calibration ...................................................................................................

Development of Water-Surface Profiles ...................................................................

Development of Flood-Inundation Maps ............................................................................

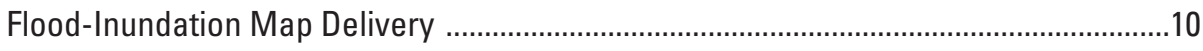

Disclaimer for Flood-Inundation Maps .......................................................................10

Uncertainties and Limitations Regarding Use of Flood-Inundation Maps .....................10

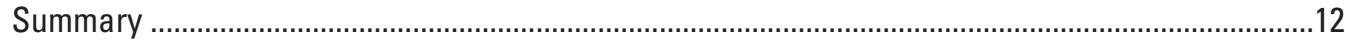

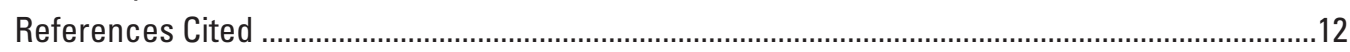

\section{Figures}

1. Graphs showing $A$, Time series of peak annual flows and $B$, associated water levels, including National Weather Service major flood stage (red dashed line), showing increasing trend in median annual peak discharges and peak water levels at the U.S. Geological Survey Huron River near Hamburg, Michigan streamgage (04172000)

2. Map showing the location of Huron River and Ore Lake tributary study reaches, stage sensor and discrete measurement of discharge locations, and the location of the U.S. Geological Survey Huron River near Hamburg, Michigan streamgage (04172000)

3. Graph showing seasonal relation between stage and discharge measurements, without ice-affected measurements, at the Huron River near Hamburg, Michigan (04172000), from base rating 5, after January 1999

4. Map showing locations of varying Manning's $n$ values for the Huron River near Hamburg, Michigan (04172000) within the modeled study reach

5. Flood-inundation map for the Huron River near Hamburg, Michigan, corresponding to a stage of 10.5 feet at the U.S. Geological Survey streamgage (station number 04172000) 


\section{Tables}

1. Information for U.S. Geological Survey Huron River near Hamburg, Michigan streamgage (04172000)

2. Estimated discharges corresponding to stage and water-surface elevations at select locations

3. Measured discharges for specific dates at U.S. Geological Survey streamgages 04171800, Little Ore Lake Outlet near Hamburg, Michigan, and 04172000, Huron River near Hamburg, Michigan, and estimated discharge for specific dates at the Huron River upstream of the Ore Lake Tributary

4. Comparison of modeled and measured water-surface elevations on July 24, 2015, at selected locations along the Huron River and Ore Lake Tributary during a high-water period due to aquatic growth

5. Comparison of modeled and measured water-surface elevations at the U.S. Geological Survey streamgage on Huron River near Hamburg, Michigan (station number 04172000) 


\section{Abbreviations and Acronyms}

\begin{tabular}{ll}
\hline \multicolumn{1}{c}{ Abbreviation or acronym } & \multicolumn{1}{c}{ Definition } \\
\hline AHPS & Advance Hydrologic Prediction Service \\
DEM & Digital elevation model \\
FIS & Flood insurance study \\
HEC-RAS & Hydrologic Engineering Center River Analysis System \\
lidar & Light detection and ranging \\
NAD 83 & North American Datum of 1983 \\
NAVD 88 & North American Vertical Datum of 1988 \\
NWS & National Weather Service \\
RTK & Realtime kinematic \\
USACE & U.S. Army Corps of Engineers \\
USGS & U.S. Geological Survey \\
\hline
\end{tabular}

\section{Conversion Factors}

U.S. customary units to International System of Units

\begin{tabular}{lcl}
\hline \multicolumn{1}{c}{ Multiply } & By & \multicolumn{1}{c}{ To obtain } \\
\hline foot $(\mathrm{ft})$ & Length & meter $(\mathrm{m})$ \\
mile $(\mathrm{mi})$ & 0.3048 & kilometer $(\mathrm{km})$ \\
\hline & 1.609 & \\
\hline square mile $\left(\mathrm{mi}^{2}\right)$ & Area & square kilometer $\left(\mathrm{km}^{2}\right)$ \\
\hline & 2.590 & \\
\hline cubic foot per second $\left(\mathrm{ft}^{3} / \mathrm{s}\right)$ & Flow rate & cubic meter per second $\left(\mathrm{m}^{3} / \mathrm{s}\right)$ \\
\hline
\end{tabular}

\section{Datum}

Vertical coordinate information is referenced to (1) stage, the height above an arbitrary datum established at a streamgage, and (2) elevation, the height above the North American Vertical Datum of 1988 (NAVD 88).

Horizontal coordinate information is referenced to the North American Datum of 1983 (NAD 83). 



\title{
Hydraulic Modeling and Flood-Inundation Mapping for the Huron River and Ore Lake Tributary, Livingston County, Michigan
}

\author{
By Julia G. Prokopec
}

\section{Abstract}

Digital flood-inundation maps for an 8-mile (mi) reach of the Huron River near Hamburg, Michigan (station number 04172000), from downstream of Rickett Road to Strawberry Lake, were created by the U.S. Geological Survey (USGS), in cooperation with Green Oak and Hamburg Townships, Michigan, and the U.S. Army Corps of Engineers. The floodinundation maps also include a 1.16-mi reach of the Ore Lake Tributary until it joins the Huron River, approximately $2.22 \mathrm{mi}$ downstream of Rickett Road. The flood-inundation maps, which can be accessed through the USGS Flood Inundation Mapping Science website at http://water.usgs.gov/osw/flood inundation/, depict estimates of the areal extent and depth of flooding corresponding to selected water levels (stages) at the USGS streamgage on the Huron River near Hamburg, Michigan (station number 04172000). Near real-time stages at this streamgage may be obtained on the Internet from the USGS National Water Information System at http://waterdata. usgs.gov/ or the National Weather Service (NWS) Advanced Hydrologic Prediction Service at http:/water.weather.gov/ ahps/. The NWS Advanced Hydrologic Prediction Service also provides forecasted flood hydrographs at this website.

Flood profiles were computed for the stream reach by means of a one-dimensional step-backwater model. The hydraulic model was calibrated by using the current stagedischarge relation at the Huron River near Hamburg, Mich., streamgage and was calibrated to water levels determined with stage sensors (pressure transducers) temporarily deployed along the stream reach. The hydraulic model was used to compute a set of water-surface profiles for flood stages ranging from 7.0 to 10.5 feet (ft). This range represents stages just above 6.0 (bankfull) to $2.04 \mathrm{ft}$ above the maximum recorded stage at the USGS streamgage on the Huron River near Hamburg, Mich. (station number 04172000). The computed water-surface profiles were then combined with a Geographic Information System digital elevation model (derived from light detection and ranging [lidar] data having a $0.49-\mathrm{ft}$ vertical accuracy and 3.8-ft horizontal resolution) to delineate the area flooded at each water level.

The availability of these maps, along with Internet information regarding current stage and forecasted high-flow stages from the NWS, will provide emergency management personnel and residents with information critical for floodresponse activities such as evacuations, road closures, and postflood recovery efforts.

\section{Introduction}

Green Oak and Hamburg Townships in Livingston County, Michigan, are small communities with estimated populations of 17,476 and 21,165, respectively (U.S. Bureau of Census, 2010a and b). An upward trend in discharge and water levels has resulted in more frequent flooding from the Huron River in Green Oak and Hamburg Townships, as indicated by the time series of annual peak water levels at U.S. Geological Survey's (USGS) streamgage 04172000 Huron River near Hamburg, Mich. (fig. 1). Flood-mitigation efforts after the 2004 flood event have included removal of aquatic vegetation starting at USGS streamgage on Hamburg Road and continuing downstream towards Strawberry Lake. Growth of aquatic vegetation, mainly eelgrass, can cause backwater conditions on the Huron River. With backwater conditions, heavy rains during the growing season can lead to increased flooding (Hamburg Township, 2014).

Prior to this study, emergency responders in Hamburg Township relied on several information sources (all of which are available on the Internet) to make decisions on how to best alert the public regarding flood conditions and mitigate flood damages. One source is the Federal Emergency Management Agency's flood insurance study (FIS) for Hamburg Township, dated 2008 (Federal Emergency Management Agency, 2008). A second source is the USGS streamgage, Huron River near Hamburg, Mich. (04172000), from which current (U.S. Geological Survey, 2016a) and historical (since October 1951; U.S. Geological Survey, 2016b) water levels and discharges, including annual peak flows, can be obtained. A third source is the National Weather Service (NWS) Advanced Hydrologic Prediction Service (AHPS), which displays stage data and forecasts possible stages at the USGS Huron River near Hamburg, Mich., streamgage (04172000) (National Weather Service, 2016a). Throughout this report, the USGS streamgage Huron River near Hamburg, Mich., (04172000) will be referred to as the Huron River streamgage. 

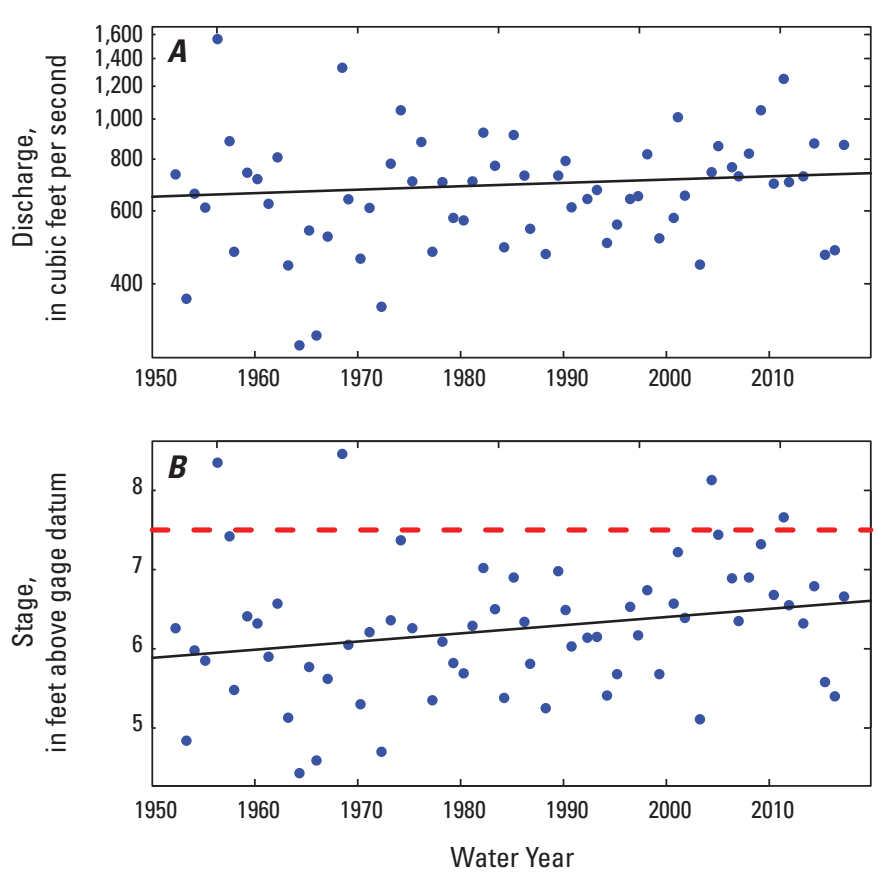

Figure 1. A, Time series of peak annual flows (discharge, in cubic feet per second) and $B$, associated water levels (feet), including National Weather Service major flood stage (red dashed line), showing increasing trend in median annual peak discharges and peak water levels at the U.S. Geological Survey Huron River near Hamburg, Michigan streamgage (04172000).

Although the current stage at a USGS streamgage is particularly useful for residents in the immediate vicinity of a streamgage, it is of limited use to residents further upstream or downstream given the water-surface elevation is not constant along the entire stream reach. Knowledge of a water level at a streamgage is difficult to translate into depth and areal extent of flooding at points distant from the streamgage. One way to address these informational gaps is to produce a library of flood-inundation maps referenced to the various stages recorded at a specific USGS streamgage. By referring to the appropriate map, emergency responders can discern the severity of flooding (depth of water and areal extent), identify roads that are or will soon be flooded, and make plans for notification or evacuation of residents in harm's way for some distance upstream and downstream of a specified streamgage. In addition, the capability to visualize the potential extent of flooding has been shown to motivate residents to take precautions and heed warnings that they previously might have disregarded. In 2015, the USGS, in cooperation with Green Oak and Hamburg Townships and the U.S. Army Corps of Engineers (USACE), conducted a project to produce a library of flood-inundation maps for a segment of the Huron River near Hamburg, Mich., and one of its tributaries, Ore Lake.

\section{Purpose and Scope}

The purpose of this report is to provide a library of estimated flood-inundation maps for portions of Green Oak and Hamburg Townships, in Livingston County, Mich., adjacent to an 8-mile (mi) reach of the Huron River and its tributary, Ore Lake (fig. 2). The maps were produced for flood levels referenced to the stage recorded at the USGS streamgage on the Huron River near Hamburg (table 1); the gage is located on Hamburg Road Bridge in the middle of the study reach, approximately $0.5 \mathrm{mi}$ downstream from the Ore Lake Tributary confluence to the Huron River. The maps cover a range of stages at $0.5 \mathrm{ft}$ increments from $7.0 \mathrm{ft}$ to $10.5 \mathrm{ft}$. The $6.0-\mathrm{ft}$ stage is approximately bankfull for the Huron River near Hamburg, Michigan, and is defined by the NWS (2016b) as the "action stage" or that stage which, when reached by a rising stream, requires the NWS or a partner to take some type of mitigation action in preparation for possible significant hydrologic activity. The 7.5 -ft stage is defined by the NWS (2016b) as the "major flooding" or that stage which is characterized by extensive inundation and usually the evacuation of people and closure of both primary and secondary roads. The 10.5 -ft stage exceeds the maximum recorded peak stage by $2.04 \mathrm{ft}$ (table 1 ).

The map library identifies areas likely to be flooded throughout a broad range of hydrologic conditions. Real-time streamflow data for the Huron River streamgage supports forecasts by the NWS that are used to guide the selection of flood-inundation maps. These flood-inundation maps, corresponding to stage or forecasted stage, are made freely available to the public through the Internet.

\section{Study Area Description}

Green Oak and Hamburg Townships are in the lower peninsula of Michigan about 25 mi northwest of Ann Arbor, Mich. (fig. 2). Green Oak and Hamburg Townships are in the southeastern corner of Livingston County. The Huron River is the largest river in Livingston County.

The study reach covers approximately 8 miles of the Huron River from downstream of Rickett Road to Strawberry Lake. The area also includes Ore Lake and Little Ore Lake tributary (herein referred to as Ore Lake Tributary) which is confluent with the Huron River approximately $0.5 \mathrm{mi}$ upstream the Huron River streamgage. The study reach is traversed by five bridges: Riverside Drive, Hamburg Road, West Michigan 36, Lakelands Trail State Park pedestrian bridge, and a railroad bridge. The drainage area of the Huron River and Ore Lake Tributary at the downstream extent of the study reach is 355 square miles. Within the study limits of this project, the drainage area is mostly residential, public lands, conserved open space, and undeveloped lands (Hamburg Township, 2011). 


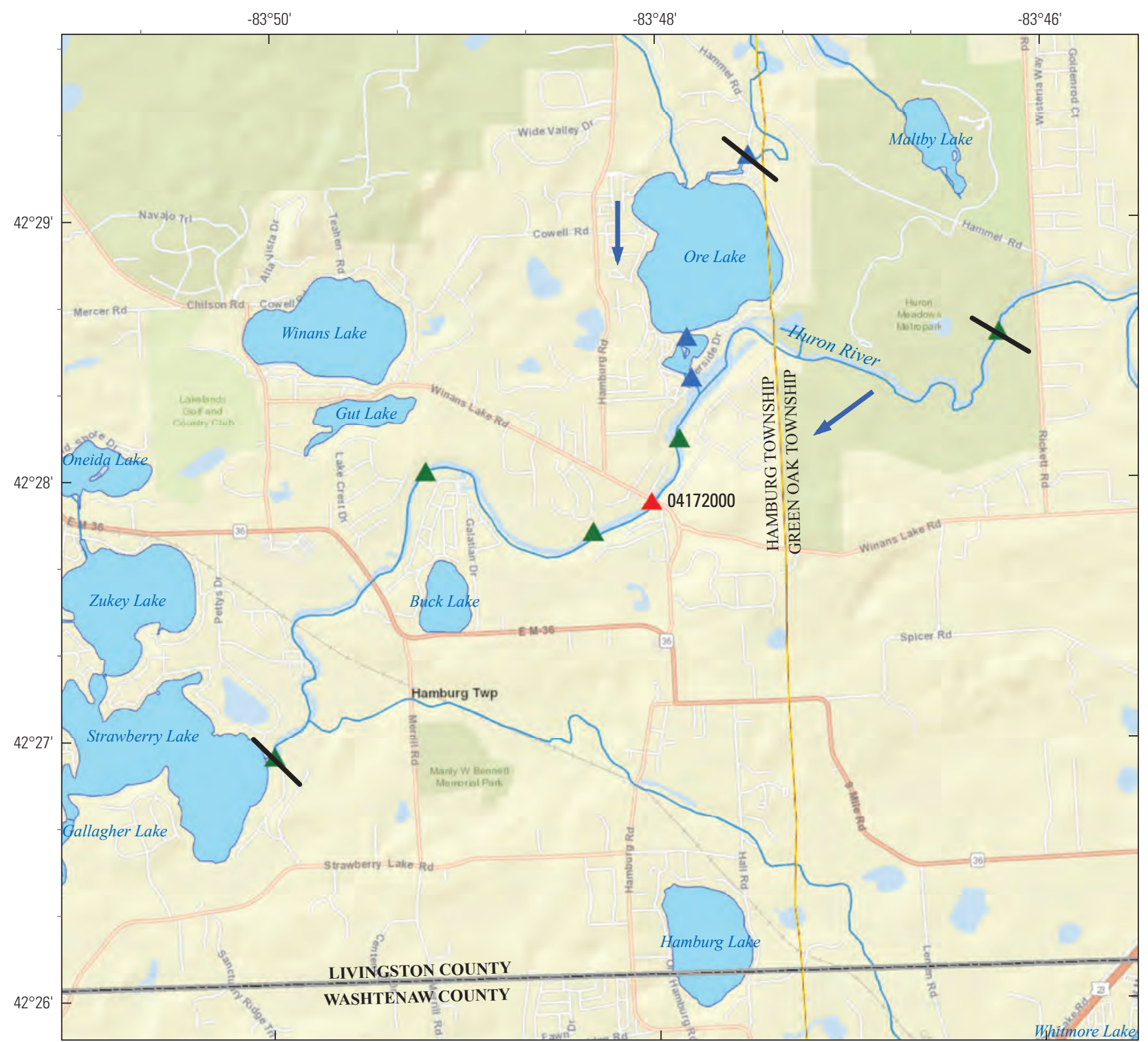

Map image is the intellectual property of Esri and isused herein under license. Copyright (C) 2014 Esri and its licensors. All rights reserved.

Universal Transverse Mercator, projection, zone 17

North American Datum 1983

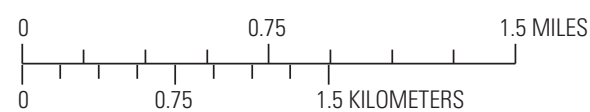

\section{EXPLANATION}
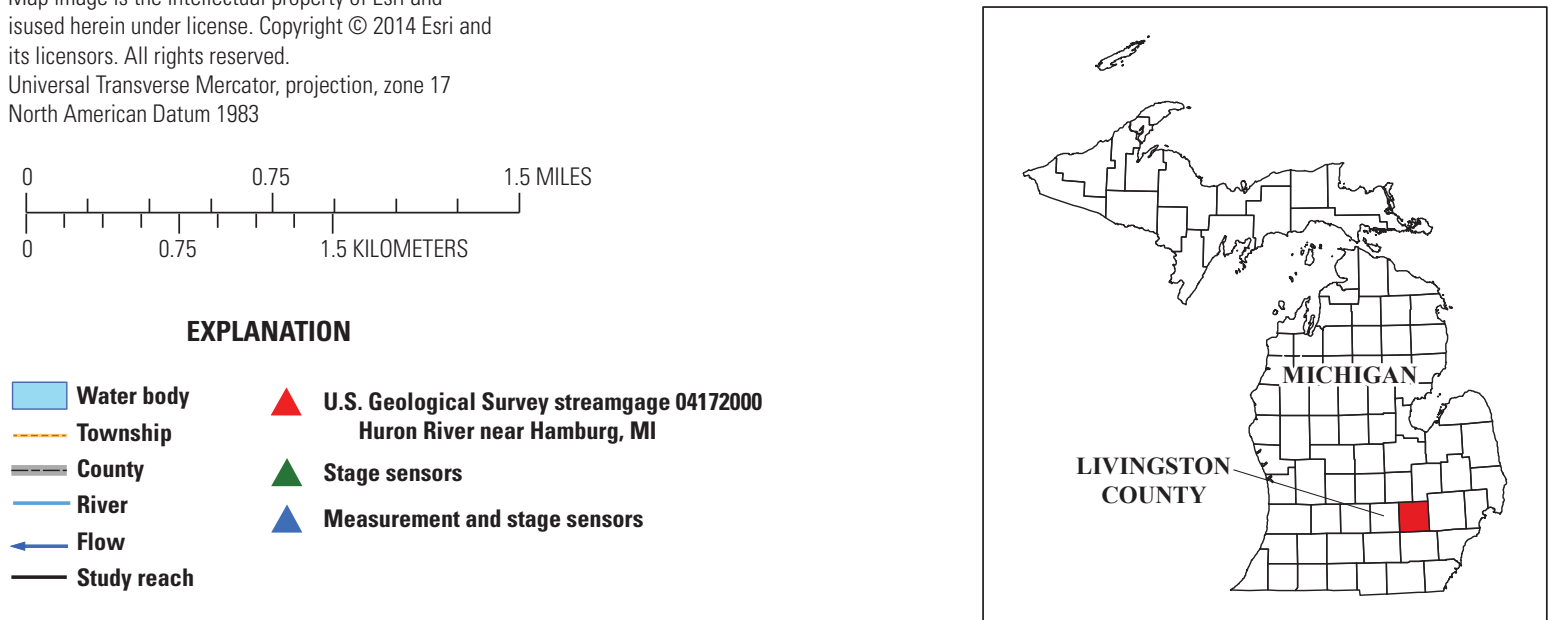

Figure 2. The location of Huron River and Ore Lake tributary study reaches, stage sensor and discrete measurement of discharge locations, and the location of the U.S. Geological Survey Huron River near Hamburg, Michigan streamgage (04172000). 
Table 1. Information for U.S. Geological Survey Huron River near Hamburg, Michigan streamgage (04172000).

[Station location is shown in figure $1 . \mathrm{mi}^{2}$, square miles; $\mathrm{ft}^{3} / \mathrm{s}$, cubic feet per second; NAVD 88, North American Vertical Datum of 1988]

\begin{tabular}{lc}
\hline \multicolumn{1}{c}{ Station name } & $\begin{array}{c}\text { Huron River } \\
\text { near Hamburg, } \\
\text { Mich. }\end{array}$ \\
\hline Station number & 04172000 \\
Drainage area $\left(\mathrm{mi}^{2}\right)$ & 308 \\
Latitude & $42^{\circ} 27^{\prime} 55^{\prime \prime}$ \\
Longitude & $83^{\circ} 47^{\prime} 59^{\prime \prime}$ \\
Period of peak-flow record (water years $\left.{ }^{1}\right)$ & $1952-2016$ \\
Maximum recorded stage, in feet, gage datum & 8.46 \\
$\quad$ and elevation, in feet above NAVD 88$)$ & $(858.13)$ \\
$\quad$ and date & June 30, 1968 \\
Maximum discharge, in $\mathrm{ft}^{3} / \mathrm{s}$, & 1,560 \\
$\quad$ and date & May 15,1956 \\
\hline
\end{tabular}

${ }^{1}$ Water year is the 12-month period from October 1 of one year through September 30 of the following year and is designated by the calendar year in which it ends.

\section{Previous Studies}

The most recent FIS for Livingston County, Michigan was published in 2008 (Federal Emergency Management Agency, 2008). The 2008 report updated the 1984 FIS for Green Oak Township (Federal Emergency Management Agency, 1984) and the 1986 FIS for Hamburg Township (Federal Emergency Management Agency, 1986). The previous flood elevations were based upon hydraulic data and hydrologic analyses completed in July 1983 for Green Oak Township and May 1985 for Hamburg Township. The 2008 FIS update redelineated flood-plain boundaries based on more detailed topographic information made available after the 1983 and 1985 studies. The 2008 FIS did not include updated hydrology or hydraulics in the study area, only a redelineation of the flood-plain boundaries on the updated topography.

\section{Creation of Flood-Inundation-Map Library}

The USGS has standardized the procedures for creating flood-inundation maps for flood-prone communities (U.S. Geological Survey, 2016c) so that the process followed and products produced are similar regardless of which USGS office is responsible for the work. Tasks specific to development of the flood maps for Green Oak and Hamburg Townships, Mich., were the (1) collection of topographic and bathymetric data for selected cross sections and geometric data for structures and bridges along the study reach, (2) estimation of energy-loss factors (roughness coefficients and flow expansion and contraction loss coefficients) in the stream channel and flood plain and determination of steady-floodflow rates used in hydraulic computations, (3) computation of water-surface profiles using the USACE Hydrologic Engineering Center-River Analysis System (HEC-RAS) computer program (U.S. Army Corps of Engineers, 2010), (4) production of estimated flood-inundation maps at various stream stages using the USACE HEC-GeoRAS computer program (U.S. Army Corps of Engineers, 2009) and a geographic information system (GIS), and (5) preparation of the maps, both as shapefile polygons that depict the areal extent of flood inundation and as depth grids that provide the depth of floodwaters, for display on a USGS floodinundation mapping application.

\section{Computation of Water-Surface Profiles}

The water-surface profiles used to produce the eight flood-inundation maps in this study were computed by using HEC-RAS, version 4.1.0 (U.S. Army Corps of Engineers, 2010). HEC-RAS is a one-dimensional step-backwater model for simulation of water-surface profiles with steady-state (gradually varied) or unsteady-state flow computation options.

\section{Hydrologic Data}

The study reach includes one streamgage (Huron River streamgage; fig. 2; table 1) that has been in operation since October 1951. Stage is measured every 15 minutes, transmitted hourly by a satellite radio in the streamgage, and made available on the Internet through the USGS National Water Information System (NWIS; U.S. Geological Survey, 2016b). Stage data from this streamgage are referenced to North American Vertical Datum of 1988 (NAVD 88). Continuous records of streamflow are computed from a stage-discharge relation specific to the gaging station and are available through the USGS NWIS website. The study reach included six temporary stage sensors (pressure transducers) that collected stage data in 15-minute intervals.

For the Huron River streamgage, the stage-discharge relation (rating) was used to determine the flow for the study reach corresponding to the target stage value (base rating number 5.0, effective 1999) (table 2). Summer months, from approximately May to September, have higher watersurface elevations compared to the winter months for the same discharge value. Aquatic vegetation contributes to the higher water-surface elevations during the warmer months, because the vegetation can cause backwater conditions along the Huron River thus raising water stages and causing a shift in the rating (fig. 3). Peak flows from the May 25, 2004, flood were used in the final model simulations, to which a $-2.0 \mathrm{ft}$ shift was applied due to dense aquatic vegetation in the channel. The base rating number 5.0, which covers water level ranges from $2.81 \mathrm{ft}$ to $9.21 \mathrm{ft}$, was extended to include higher stages by use of a straight-line extension of log-log plot. 


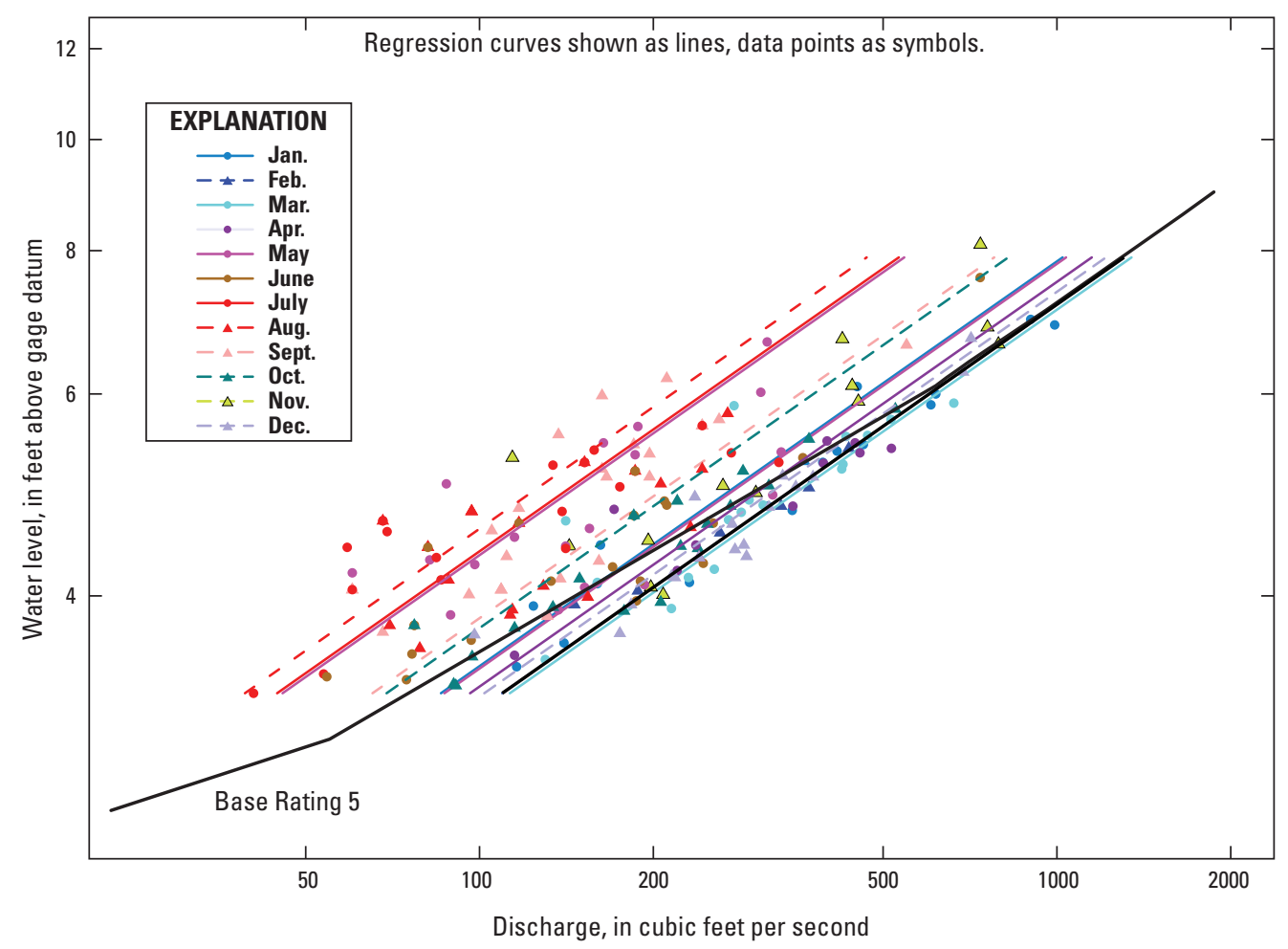

Figure 3. Seasonal relation between stage and discharge measurements, without ice-affected measurements, at the Huron River near Hamburg, Michigan (04172000), from base rating 5, after January 1999.

An average percent contribution of streamflow from discrete discharge measurements at USGS 04171800 Little Ore Lake Outlet near Hamburg, Mich., to the Huron River was used to determine the streamflow of Ore Lake Tributary and the upstream portion of the Huron River's (table 3).

\section{Topographic and Bathymetric Data}

All overbank topographic and channel bathymetry data used in this study are referenced vertically to NAVD 88 and horizontally to the North American Datum of 1983 (NAD 83). Cross-section elevation data were obtained from a digital elevation model (DEM) that was derived from light detection and ranging (lidar) data collected March 2010 by Woolpert, Inc., Dayton, Ohio (Woolpert, 2010). Postprocessing of these data was completed by Woolpert, Inc. on April 2010, and the final DEM was provided to the USGS by the Livingston County GIS Department. The lidar data have horizontal resolution of $3.8 \mathrm{ft}$ (1.16 meters) and vertical accuracy of $0.49 \mathrm{ft}$ ( 0.15 meters) at a 95 percent confidence interval for the open terrain landcover category.

Through the use of HEC-GeoRAS, which utilizes a set of procedures, tools, and utilities for processing geospatial data in ArcGIS, elevation data were extracted from the DEM for 112 cross sections and subsequently were input to the HEC-RAS model. Because lidar data cannot provide ground elevations below a stream's water surface, select channel cross sections were surveyed by USGS personnel during September 2014. Crosssectional depths were measured by wading at 23 locations, including upstream and downstream from all hydraulic structures. A differential global positioning system with real-time kinematic (RTK) technology was used to derive horizontal locations and the elevation of the water surface at each surveyed cross section. Elevations determined by RTK at two benchmark locations were within $0.03-0.11 \mathrm{ft}$ of the known elevations, an error range that is less than the uncertainty of the lidar data.

DEM-generated cross sections coincide with all locations where channel cross sections were obtained during the field surveys. In these cases, within-channel data were directly merged with the DEM data. For all other cross sections, the within-channel data were estimated by interpolation from the closest field-surveyed cross section. The average distance between field-surveyed cross sections along the Huron River channel and Ore Lake Tributary were 1,660 ft and $743 \mathrm{ft}$, respectively, for a total average distance of $1,400 \mathrm{ft}$. 
Table 2. Estimated discharges corresponding to stage and water-surface elevations at select locations.

[Locations shown in figure 1. ft, feet; NAVD 88, North American Vertical Datum of 1988]

\begin{tabular}{|c|c|c|c|c|}
\hline \multirow{2}{*}{$\begin{array}{l}\text { Stage of water- } \\
\text { surface profile } \\
\text { (ft) }{ }^{1}\end{array}$} & \multirow{2}{*}{$\begin{array}{l}\text { Water-surface } \\
\text { elevation } \\
\text { (ft, NAVD 88) }\end{array}$} & \multicolumn{3}{|c|}{$\begin{array}{l}\text { Estimated discharge at indicated location, } \\
\text { in cubic feet per second }\end{array}$} \\
\hline & & $\begin{array}{l}\text { Upstream from confluence } \\
\text { with Ore Lake Tributary }\end{array}$ & Ore Lake Tributary & $\begin{array}{l}\text { Downstream end } \\
\text { of study reach }\end{array}$ \\
\hline 7.0 & 856.67 & 384 & 64 & 448 \\
\hline 7.5 & 857.17 & 486 & 81 & 567 \\
\hline 8.0 & 857.67 & 603 & 101 & 704 \\
\hline 8.5 & 858.17 & 755 & 126 & 881 \\
\hline 9.0 & 858.67 & 926 & 154 & 1,080 \\
\hline 9.5 & 859.17 & 1,116 & 186 & 1,302 \\
\hline 10.0 & 859.67 & 1,325 & 221 & 1,546 \\
\hline 10.5 & 860.17 & 1,553 & 259 & 1,812 \\
\hline
\end{tabular}

\begin{tabular}{|c|c|c|c|c|}
\hline \multirow{2}{*}{$\begin{array}{l}\text { Stage of water- } \\
\text { surface profile } \\
\text { (ft })^{1}\end{array}$} & \multirow{2}{*}{$\begin{array}{c}\text { Water-surface } \\
\text { elevation } \\
\text { (ft, NAVD 88) }\end{array}$} & \multicolumn{3}{|c|}{$\begin{array}{l}\text { Estimated discharge at indicated location, } \\
\text { in cubic feet per second }\end{array}$} \\
\hline & & $\begin{array}{l}\text { Huron River from Rickett } \\
\text { Road to Ore Lake } \\
\text { Tributary confluence }\end{array}$ & $\begin{array}{l}\text { Little Ore Lake Outlet } \\
\text { near Hamburg, Mich. } \\
\text { (USGS 04171800) }\end{array}$ & $\begin{array}{l}\text { Huron River near } \\
\text { Hamburg, Mich. } \\
\text { (USGS 04172000) }\end{array}$ \\
\hline 7.0 & 856.67 & 384 & 64 & 448 \\
\hline 7.5 & 857.17 & 486 & 81 & 567 \\
\hline 8.5 & 858.17 & 755 & 126 & 881 \\
\hline 9.0 & 858.67 & 926 & 154 & 1,080 \\
\hline 9.5 & 859.17 & 1,116 & 186 & 1,302 \\
\hline 10.0 & 859.67 & 1,325 & 221 & 1,546 \\
\hline
\end{tabular}

${ }^{1}$ Water-surface profiles are 0.50 -foot increments of stage, referenced to the gage datum of the U.S. Geological Survey streamgage, Huron River near Hamburg, Michigan (station number 04172000).

\section{Hydraulic Structures}

Along the study reach, five structures - consisting of three road crossings (Riverside Drive, Hamburg Road, County Road West Michigan 36), the Lakelands Trail State Park pedestrian bridge, and a railroad bridge - have the potential to affect water-surface elevations during high-flow conditions. Structure-geometry data were obtained from field surveys by USGS personnel who used RTK surveying techniques. Structure geometry and loss coefficients were input to the hydraulic model and water-surface profiles were computed seamlessly with the channel cross-section data in HEC-RAS.

\section{Energy-Loss Factors}

Hydraulic analyses require the estimation of energy losses that result from frictional resistance exerted by a channel on flow or losses associated with flow expansion and contraction. These frictional energy losses are quantified by the Manning's roughness coefficient (" $n$ " value). Initial (precalibration) $n$ values were selected by comparing field observations with information from the May 25, 2004, Declaration of Disaster (Hamburg Township, 2014) (which details flooded areas related to stage at the Huron River streamgage). An initial $n$ value of 0.030 was selected for the area of the Huron River with a wider, low-gradient, main channel, a silty bed and tree-lined banks. This section is between Rickett Road to the Huron River streamgage. An initial $n$ value of 0.095 was selected for a section of the Huron River that contains dense invasive aquatic vegetation. Forested and residential areas cover wide swaths of land on both banks and flood plains adjacent to the Ore Lake Tributary and the Huron River. A composite $n$ value (0.06) that is thought to represent the diverse energy-loss factors of these land types was used for the initial estimate of the flood plain $n$ value. 
Table 3. Measured discharges for specific dates at U.S. Geological Survey streamgages 04171800, Little Ore Lake Outlet near Hamburg, Michigan, and 04172000, Huron River near Hamburg, Michigan, and estimated discharge for specific dates at the Huron River upstream of the Ore Lake Tributary.

[Locations are shown in figure 1. Date in month/day/year; USGS, U.S. Geological Survey; EST, eastern standard time; $\mathrm{ft}^{3} / \mathrm{s}$, cubic feet per second]

\begin{tabular}{lccc}
\hline Date and time & $\begin{array}{c}\text { Streamflow }\left(\mathbf{f t}^{3} / \mathbf{s}\right) \text { Little Ore Lake } \\
\text { Outlet near Hamburg, Mich. } \\
\text { (USGS 04171800) }\end{array}$ & $\begin{array}{c}\text { Streamflow }\left(\mathbf{f t}^{3} / \mathbf{s}\right) \text { Huron River } \\
\text { near Hamburg, Mich. } \\
\text { (USGS 04172000) }\end{array}$ & $\begin{array}{c}\text { Estimated streamflow }\left(\mathbf{f t}^{3} / \mathbf{s}\right) \\
\text { from Rickett Road to } \\
\text { Ore Lake Tributary }\end{array}$ \\
\hline 7/9/2015 09:30 EST & 27.0 & 184 & 157 \\
7/24/2015 10:30 EST & 19.0 & 137 & 118 \\
8/12/2015 12:15 EST & 28.2 & 172 & 144 \\
8/26/2015 10:00 EST & 13.5 & 93 & 79.5 \\
9/16/2015 10:00 EST & 12.0 & 80 & 92
\end{tabular}

\begin{tabular}{lccc}
\hline Date and time & $\begin{array}{c}\left.\text { Estimated streamflow } \mathbf{f t t}^{3} / \mathbf{s}\right) \text { of } \\
\text { the Huron River from Rickett } \\
\text { Road to Ore Lake Tributary } \\
\text { confluence }\end{array}$ & $\begin{array}{c}\text { Streamflow }\left(\mathbf{f t}^{3} / \mathbf{s}\right) \text { Little Ore Lake } \\
\text { Outlet near Hamburg, Mich. } \\
\text { (USGS 04171800) }\end{array}$ & $\begin{array}{c}\text { Streamflow }\left(\mathbf{f t}^{3} / \mathbf{s}\right) \text { Huron River } \\
\text { near Hamburg, Mich. } \\
\text { (USGS 04172000) }\end{array}$ \\
\hline 7/9/2015 09:30 EST & 157 & 27.0 & 184 \\
7/24/2015 10:30 EST & 118 & 19.0 & 137 \\
8/12/2015 12:15 EST & 144 & 28.2 & 172 \\
8/26/2015 10:00 EST & 79.5 & 13.5 & 93 \\
9/16/2015 10:00 EST & 92 & 12.0 & 80 \\
\hline
\end{tabular}

As part of the calibration process, the initial $n$ values were varied by flow and aquatic vegetation growing season and adjusted until the differences between simulated and observed water-surface elevations at the streamgage and stream sensors were minimized. Final $n$ values ranged from 0.035 to 0.095 for the main channel of the Huron River to represent the aquatic growing season, and 0.06 for the overbank areas (fig. 4).

\section{Hydraulic Model}

The HEC-RAS analysis for this study included two stream reaches, the Huron River and Ore Lake Tributary, and was based on a one-dimensional, steady-state flow computation that included a junction where the two stream reaches meet. Steady-state flow data consisted of flow regime, boundary conditions, and peak flows that produced watersurface elevations at the streamgage cross section that matched target water-surface elevations within $0.75 \mathrm{ft}$. Target elevations coincided with 0.5 -ft increments of stage, referenced to the Huron River streamgage datum. Subcritical (tranquil) flow regime was assumed for the simulations. Normal depth, based on an estimated average water-surface slope of 0.000052 , was used as the Huron River reach's downstream boundary condition to accommodate possible backwater flow at the end of the study reach from the inlet of Strawberry Lake. The calculated water-surface slope between the last two downstream stage sensors on the Huron River was $0.00027 \mathrm{ft}$, which caused an abrupt decrease in water-surface elevations at the downstream boundary of the model. A water-surface slope of $0.000052 \mathrm{ft}$ minimized differences between modeled and observed values over the Huron River study reach, which provided internal consistency in the model. Peak flows used in the model are discussed in the section "Hydrologic Data."

Ore Lake Tributary is subject to backwater conditions from the Huron River. To account for concurrent flooding from the tributary, the hydraulic model joined the two streams together by means of a junction. As a result, the model used water-surface elevations from the Huron River as downstream boundary conditions for the Ore Lake Tributary.

\section{Model Calibration}

The HEC-RAS model was calibrated by varying $n$ values to improve the match between measured and simulated flows and water levels. Measured flows and water levels used the current (base rating 5.0, effective 1999) stage-discharge relation at the Huron River streamgage. Six stage sensors (pressure transducers) were installed at separate locations along the modeled reaches of the stream and tributary in May 2015, providing additional water-level data for calibration (fig. 2). RTK surveys were conducted to establish the vertical datum of each stage sensor relative to NAVD 88. The stage sensors were checked, data were downloaded, and sensors were cleaned three times during their 6-month deployment. The stage sensors were removed in November 2015. 


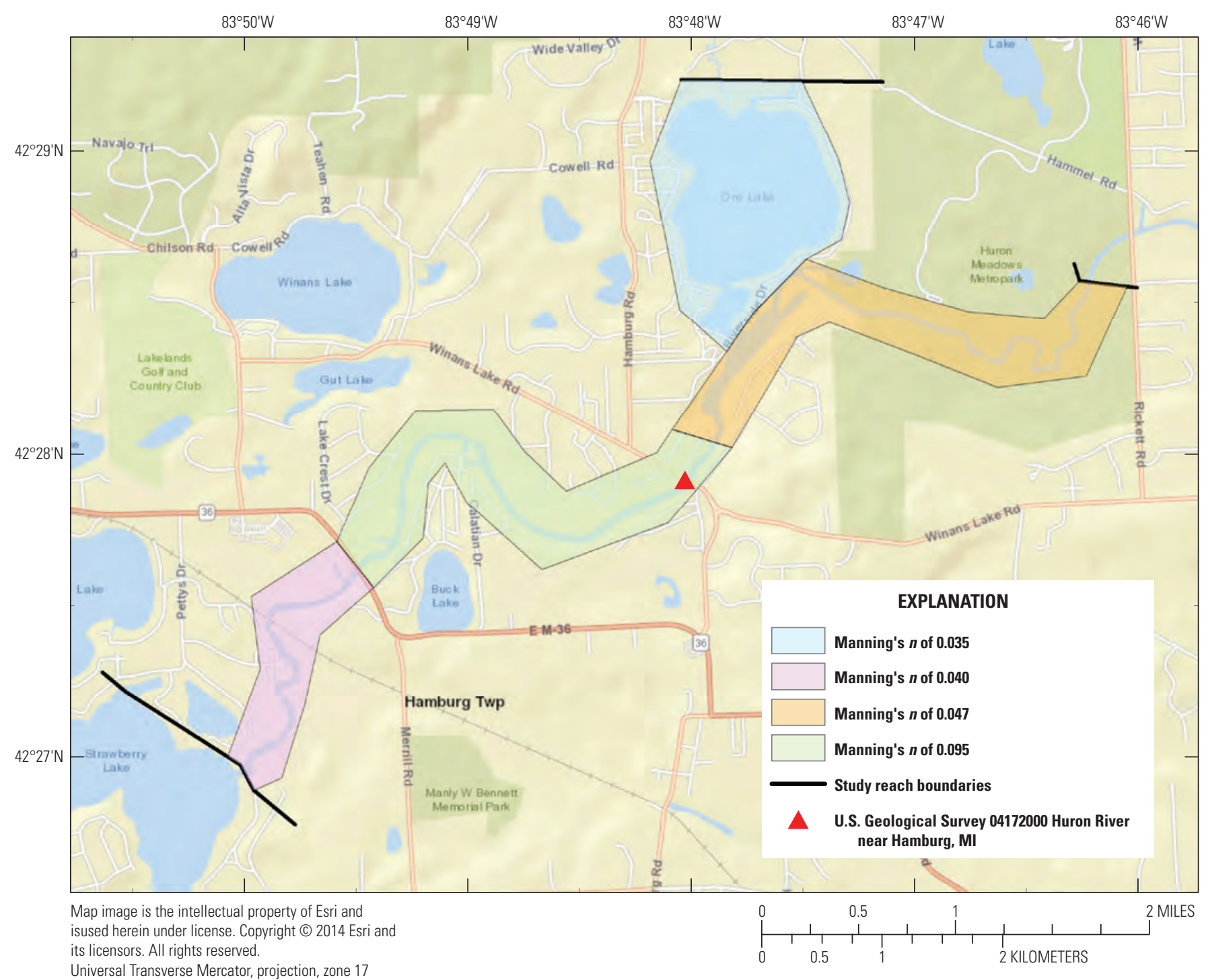

North American Datum 1983

Figure 4. Locations of varying Manning's $n$ values for the Huron River near Hamburg, Michigan (04172000) within the modeled study reach.

Stages measured during this period were low to moderate, ranging from 3.54 to $6.21 \mathrm{ft}$ at the Huron River streamgage. The streamflow value used to calibrate the HECRAS model for aquatic growing season months was 137 cubic feet per second for the Huron River Streamgage on July 24, 2015, and was obtained from base rating 5 from the Huron River streamgage, with a $-2.0 \mathrm{ft}$ shift to account for aquatic vegetation at the streamgage. Flows from July 24, 2015, were used because of ideal/worst case scenario backwater conditions that were best fit for model calibration due to high water surface elevations during peak aquatic vegetation growth. After calibration, the modeled elevations from sensors and the measured elevation from the streamgage on July 24, 2015 , had a root mean square error of $0.68 \mathrm{ft}$, with a maximum difference of $-0.89 \mathrm{ft}$ (table 4).
Discrete discharge measurements were made monthly from July 2015 to September 2015 at three locations along Ore Lake Tributary (fig. 2) during periods when flow varied from 81 to 184 cubic feet per second at the Huron River streamgage. The flow measurements were used to modeled streamflow on the Huron River upstream from Ore Lake Tributary and for Ore Lake Tributary.

The model was calibrated by adjusting Manning's $n$ values until the results of the hydraulic computations closely agreed with the measured water-surface elevations for given flows. Differences between observed and simulated watersurface elevations for eight simulated flows at the Huron River streamgage were equal to or less than $0.16 \mathrm{ft}$ (table 5). The results demonstrate that the model is capable of simulating accurate water levels over a wide range of flows in the basin. 
Table 4. Comparison of modeled and measured water-surface elevations on July 24, 2015, at selected locations along the Huron River and Ore Lake Tributary during a high-water period due to aquatic growth.

[USGS, U.S. Geological Survey; ft, feet; NAVD 88, North American Vertical Datum of 1988]

\begin{tabular}{|c|c|c|c|c|c|}
\hline $\begin{array}{l}\text { USGS station name } \\
\text { and number }\end{array}$ & Description & $\begin{array}{l}\text { River } \\
\text { station'1 } \\
\text { (ft) }\end{array}$ & $\begin{array}{l}\text { Target water- } \\
\text { surface } \\
\text { elevation } \\
\text { (ft, NAVD 88) }\end{array}$ & $\begin{array}{l}\text { Modeled } \\
\text { water-surface } \\
\text { elevation } \\
\text { (ft, NAVD 88) }\end{array}$ & $\begin{array}{l}\text { Difference } \\
\text { in elevation } \\
\quad(\mathrm{ft})\end{array}$ \\
\hline \multicolumn{6}{|c|}{ Ore Lake Tributary } \\
\hline $\begin{array}{l}\text { Dibrova Lake outlet at Mohican Dr near } \\
\text { Hamburg, Mich. } \\
(04171022)\end{array}$ & Stage sensor & 6,659 & 855.26 & 854.70 & -0.56 \\
\hline $\begin{array}{l}\text { Little Ore Lake outlet near Hamburg, Mich. } \\
\qquad(04171800)\end{array}$ & Stage sensor & 339 & 855.06 & 854.54 & -0.52 \\
\hline \multicolumn{6}{|c|}{ Huron River } \\
\hline $\begin{array}{l}\text { Huron R 1,200 feet downstream from } \\
\text { Rickett Rd. near Hamburg, Mich. } \\
(04171022)\end{array}$ & Stage sensor & 30,268 & 856.24 & 855.56 & -0.68 \\
\hline $\begin{array}{l}\text { Huron River near Hamburg, Mich. } \\
(04172000)\end{array}$ & Streamgage & 16,307 & 855.20 & 854.31 & -0.89 \\
\hline $\begin{array}{l}\text { Huron River 2,300 feet Highway M-36 } \\
\text { near Hamburg, Mich. } \\
(04172004)\end{array}$ & Stage sensor & 9,562 & 854.06 & 853.34 & -0.72 \\
\hline $\begin{array}{l}\text { Huron River immediately upstream of } \\
\text { Strawberry Lake near Hamburg, Mich. } \\
(04171703)\end{array}$ & Stage sensor & 30 & 851.48 & 850.47 & -0.75 \\
\hline
\end{tabular}

${ }^{1}$ River stations are referenced to the longitudinal baseline used in the hydraulic model, referenced to the mouth.

Table 5. Comparison of modeled and measured water-surface elevations at the U.S. Geological Survey streamgage on Huron River near Hamburg, Michigan (station number 04172000).

[ft, feet; NAVD 88, North American Vertical Datum of 1988]

\begin{tabular}{cccc}
\hline $\begin{array}{c}\text { Stage of } \\
\text { water-surface } \\
\text { profile } \\
\text { (ft) }\end{array}$ & $\begin{array}{c}\text { Observed } \\
\text { water-surface } \\
\text { elevation } \\
\text { (ft, NAVD 88) }\end{array}$ & $\begin{array}{c}\text { Modeled } \\
\text { water-surface } \\
\text { elevation } \\
\text { (ft, NAVD 88) }\end{array}$ & $\begin{array}{c}\text { Difference } \\
\text { in elevation } \\
\text { (ft) }\end{array}$ \\
\hline 7.0 & 856.67 & 856.51 & -0.16 \\
7.5 & 857.17 & 857.02 & -0.15 \\
8.0 & 857.67 & 857.53 & -0.14 \\
8.5 & 858.17 & 858.09 & -0.08 \\
9.0 & 858.67 & 858.64 & -0.03 \\
9.5 & 859.17 & 859.19 & 0.02 \\
10.0 & 859.67 & 859.73 & 0.06 \\
10.5 & 860.17 & 860.27 & 0.10 \\
\hline
\end{tabular}

\section{Development of Water-Surface Profiles}

The calibrated hydraulic model was used to generate water-surface profiles for eight target stages at 0.50 -ft intervals between $7.0 \mathrm{ft}$ and $10.5 \mathrm{ft}$ as referenced to the gage datum of the Huron River streamgage. These stages correspond to water-surface elevations of $856.67 \mathrm{ft}$ and $860.17 \mathrm{ft}$, NAVD 88, respectively. Discharges corresponding to the various stages were obtained from the current stage-discharge relation (rating number 5) for the Huron River streamgage by using a $-2.0 \mathrm{ft}$ shift due to aquatic vegetation. Discharges through the study reach were adjusted, as necessary, for tributary inflow as shown in table 3.

\section{Development of Flood-Inundation Maps}

Flood-inundation maps were created for the flood plain formed along Ore Lake Tributary and the 8-mi reach of the Huron River streamgage, which has been designated 
as a NWS flood-forecast point. Flood-inundation maps were created using GIS for the eight water-surface profiles by combining the profiles created through HEC-RAS and HEC-GeoRAS and DEM data. The DEM data were derived from the same lidar data described previously in the section "Topographic and Bathymetric Data." Estimated floodinundation boundaries for each simulated profile were developed with HEC-GeoRAS software (U.S. Army Corps of Engineers, 2009), which allows the preparation of geometric data for import into HEC-RAS and processes simulation results exported from HEC-RAS (U.S. Army Corps of Engineers, 2010). Shapefile polygons and depth grids of the inundated areas for each profile were modified, as required, in the ArcMap application of ArcGIS (Esri, 2014) to ensure a hydraulically reasonable transition of the flood boundaries between modeled cross sections. The datasets used in this study are available through a data release at https://doi. org/10.5066/F79G5M11 (Prokopec, 2018).

Any inundated areas that were detached from the main channel were examined to identify subsurface connections with the main river, such as through culverts under roadways. Where such connections existed, the mapped inundated areas were retained in their respective flood maps; otherwise, the erroneously delineated parts of the flood extent were deleted. The flood-inundation areas are overlaid on high-resolution, georeferenced, aerial photographs of the study area. Bridge surfaces are shown as noninundated up to the lowest flood stage that either intersects the lowest structural chord of the bridge or completely inundates one or both approaches to the bridge. In these latter circumstances, the bridge surface is depicted as being inundated. Estimates of water depth can be obtained from the depth-grid data that are included with the flood maps on an interactive USGS mapping application described in the following section "Flood-Inundation Map Delivery." Indicated depths are limited by the spatial resolution of the DEM and may vary rapidly with time. Thus, actual depths could be significantly greater than indicated on the maps, and, in particular, should not be relied upon to assess the safety of travel. The flood map corresponding to the highest simulated water-surface profile, a stage of $10.5 \mathrm{ft}$, is presented in figure 5 .

\section{Flood-Inundation Map Delivery}

A Flood Inundation Mapping Science website (U.S. Geological Survey, 2016c) was established to make USGS flood-inundation study information available to the public. The site links to a mapping application that presents map libraries and provides detailed information on flood extents and depths for modeled sites. The mapping application enables the production of customized flood-inundation maps from the map library for Huron River near Hamburg, Mich. A link on this website connects to the USGS NWIS (U.S. Geological Survey, 2016a), which presents the current stage and streamflow for the USGS streamgage 04172000 , the streamgage that the inundation maps are referenced to in this report. A second link connects to the NWS Advanced Hydrologic Prediction Service (AHPS) site (National Weather Service, 2016a) so that the user can obtain applicable information on forecasted peak stage. The estimated flood-inundation maps are displayed in sufficient detail so that preparations for flooding and decisions for emergency response can be performed efficiently. Depending on the flood magnitude, roadways are shown as shaded (inundated and likely impassable) or not shaded (dry and passable) to facilitate emergency planning and use. A shaded building should not be interpreted to mean that the structure is completely submerged; rather that bare earth surfaces near the building are inundated. In these instances, the water depth (as indicated in the mapping application by holding the cursor over an inundated area) near the building would be an estimate of the water level inside the structure, unless flood-proofing measures had been implemented.

\section{Disclaimer for Flood-Inundation Maps}

The flood-inundation maps should not be used for navigation, regulatory, permitting, or other legal purposes. The USGS provides these maps "as-is" for a quick reference, emergency planning tool but assumes no legal liability or responsibility resulting from the use of this information.

\section{Uncertainties and Limitations Regarding Use of Flood-Inundation Maps}

Although the flood-inundation maps represent the boundaries of inundated areas with a distinct line, some uncertainty is associated with these maps. The flood boundaries shown were estimated on the basis of water stages and streamflows at selected USGS stream gages. Watersurface elevations along the stream reaches were estimated by steady-state hydraulic modeling, assuming unobstructed flow, and using streamflows and hydrologic conditions anticipated at the USGS streamgage. The hydraulic model reflects the land-cover characteristics and any bridge, dam, levee, or other hydraulic structures existing as of December 2015. Unique meteorological factors (timing and distribution of precipitation) may cause actual streamflows along the modeled reach to vary from those assumed during a flood, which may lead to deviations in the water-surface elevations and inundation boundaries shown. Additional areas may be flooded due to unanticipated conditions such as changes in the streambed elevation or roughness, backwater into major tributaries along a main stem river, or backwater from localized debris or ice jams. The accuracy of the floodwater extent portrayed on these maps will vary with the accuracy of the digital elevation model used to simulate the land surface. 


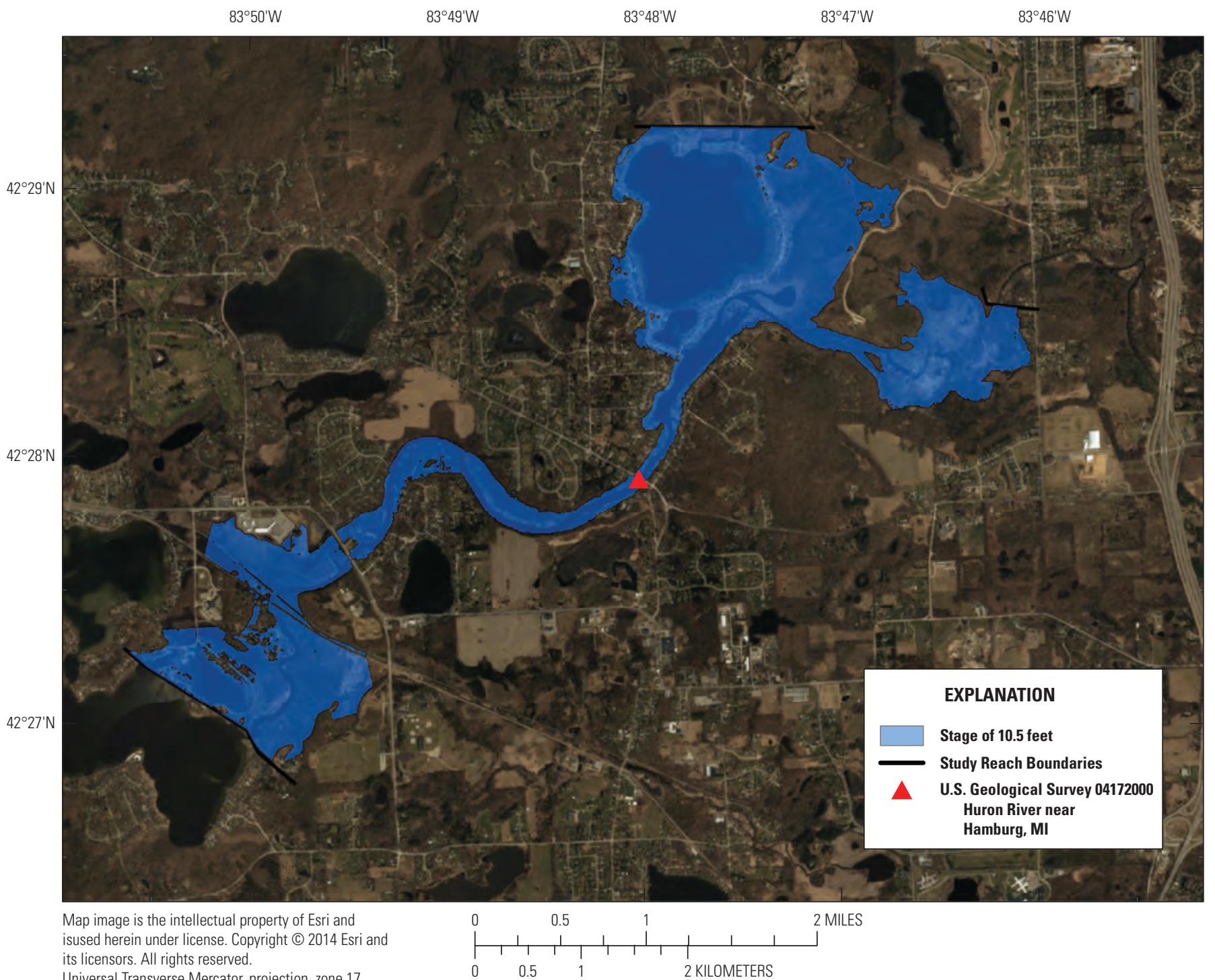

Universal Transverse Mercator, projection, zone 17

North American Datum 1983

Figure 5. Flood-inundation map for the Huron River near Hamburg, Michigan, corresponding to a stage of 10.5 feet at the U.S. Geological Survey streamgage (station number 04172000).

If this library of flood-inundation maps will be used in conjunction with NWS river forecasts, the user should be aware of additional uncertainties that may be inherent or factored into NWS forecast procedures. The NWS uses forecast models to estimate the quantity and timing of water flowing through selected stream reaches in the United States. These forecast models (1) estimate the amount of runoff generated by precipitation and snowmelt, (2) simulate the movement of floodwater as it proceeds downstream, and (3) predict the flow and stage (and water-surface elevation) for the stream at a given location (AHPS forecast point) throughout the forecast period (every 6 hours and 3 to 5 days out in many locations). For more information on AHPS forecasts, see: http://water.weather.gov/ahps/pcpn_and_river_ forecasting.pdf.

An additional source of uncertainty is the modeled watersurface elevations and depth for overbank areas due to limited calibration data during study period. Additional uncertainties and limitations pertinent to this study may be described elsewhere in this report. 


\section{Summary}

The U.S. Geological Survey (USGS), in cooperation with Green Oak and Hamburg Townships, Michigan, and the U.S. Army Corps of Engineers, developed a library of digital flood-inundation maps for an 8-mile reach of the Huron River near Hamburg, Mich. (station number 04172000), from downstream of Rickett Road to Strawberry Lake, and Ore Lake Tributary, from Ore Lake and Little Ore Lake, until its confluence with the Huron River study reach. The maps were developed by using the U.S. Army Corps of Engineer's HECRAS and HEC-GeoRAS programs and Esri's ArcGIS program to compute water-surface profiles and to delineate estimated flood-inundation areas and depths of flooding for selected stream stages. The HEC-RAS hydraulic model was calibrated to the current stage-discharge relation at the Huron River streamgage, and to water-level data measured with pressure transducers. The model was used to compute water-surface profiles at 0.5 -foot (ft) increments for flood stages from $7.0 \mathrm{ft}$ to $10.5 \mathrm{ft}$ corresponding to above bankfull to $2.04 \mathrm{ft}$ above the maximum recorded water level. The simulated water-surface profiles were then combined with a geographic information system (GIS) digital elevation model derived from light detection and ranging (lidar) data to delineate estimated flood-inundation areas as shapefile polygons and depth grids for each profile. These flood-inundation polygons were overlaid on high-resolution, georeferenced aerial photographs of the study area. The flood maps are available through a mapping application that can be accessed on the USGS Flood Inundation Mapping Science website (http://wimcloud.usgs. gov/apps/FIM/FloodInundationMapper.html).

Interactive use of the maps on this mapping application can give users a general indication of depth of water at any point by using the mouse cursor to click within the shaded areas. These maps, in conjunction with the real-time stage data from the USGS streamgage 04172000 and forecasted flood stage data from the NWS Advanced Hydrologic Prediction Service will help to guide the general public in taking individual safety precautions and will provide emergency management personnel with a tool to efficiently manage emergency flood operations and postflood recovery efforts.

\section{References Cited}

Esri, 2014, ArcGIS, accessed February 16, 2016, at http:// www.esri.com/software/arcgis/.

Federal Emergency Management Agency, 1984, Flood insurance study for the Township of Green Oak, Livingston County, Michigan; Washington, D.C., Flood Insurance Study Number 260440V000, Community Number 260440, $22 \mathrm{p}$.
Federal Emergency Management Agency, 1986, Flood insurance study for the Township of Hamburg, Livingston County, Michigan; Washington, D.C., Flood Insurance Study Number 260118V000, Community Number 260118, $21 \mathrm{p}$.

Federal Emergency Management Agency, 2008, Flood insurance study, Livingston County, Michigan (All Jurisdictions), Flood Insurance Study Number 26093CV000A, $90 \mathrm{p}$.

Hamburg Township, 2011, Master Plan, p. 27, accessed November 3, 2016, at http://www.hamburg.mi.us/ government/lawroom_(ordinances)_general_ordinances/ master_plan.php.

Hamburg Township, 2014, Flood Response Action PlanNFIP Community \#26011-Hamburg Township, Livingston County, Michigan: Hamburg Township report, 123 p., accessed December 15, 2015, at http://www.hamburg.mi.us/ government/lawroom_(ordinances)_general_ordinances/ flooding_response_action_plan.php.

National Weather Service, 2016a, Advanced Hydrologic Prediction Service, Huron River at Hamburg, accessed October 3, 2016, at http://water.weather.gov/ahps2/ hydrograph.php?wfo=dtx\&gage=hmgm 4 .

National Weather Service, 2016b, National Weather Service Glossary, accessed October 3, 2016, at http://w1.weather. gov/glossary/index.php?word=action+stage.

Prokopec, J.G., 2018, Huron River near Hamburg, Michigan, flood-inundation model and field data: U.S. Geological Survey data release, accessed February 2018, at https://doi. org/10.5066/F79G5M11.

U.S. Army Corps of Engineers, Hydrologic Engineering Center, 2009, HEC-GeoRAS, GIS Tools for Support of HEC-RAS using ArcGIS, User's Manual, version 4.2, [variously paged].

U.S. Army Corps of Engineers, Hydrologic Engineering Center, 2010, HEC-RAS River Analysis System, Hydraulic Reference Manual, version 4.1, [variously paged].

U.S. Bureau of Census, 2010a, QuickFactsPopulation, Census, April 1, 2010, Hamburg Township, Livingston County, Michigan. Accessed June 21, 2017, at https://www.census. gov/quickfacts/table/PST045216/2609336100.

U.S. Bureau of Census, 2010b, QuickFacts Population, Census, April 1, 2010, Green Oak Township, Livingston County, Michigan. Accessed June 21, 2017, at https://www.census.gov/quickfacts/fact/table/ greenoaktownshiplivingstoncountymichigan/PST045216.

U.S. Geological Survey, 2016a, USGS $<04172000>$ Huron River near Hamburg, MI: U.S. Geological Survey, accessed October 3, 2016, at http://waterdata.usgs.gov/mi/nwis/ uv/?site_no $=04172000$. 
U.S. Geological Survey, 2016b, USGS surface-water data for the Nation: U.S. Geological Survey, accessed October 3, 2016, at http://waterdata.usgs.gov/nwis/sw.

U.S. Geological Survey, 2016c, USGS Flood Inundation Mapping Science: U.S. Geological Survey, accessed October 4, 2016, at http://water.usgs.gov/osw/flood_ inundation.
Woolpert, Inc., 2010, 2010 ARRA Lidar: 4 Southeast Counties (MI)[metadata]: National Oceanic and Atmospheric Administration, Woolpert Order No. 70398, prepared by Woolpert, Inc., Geospatial Services [Dayton, Ohio], accessed January 31, 2018, at https://coast.noaa.gov/htdata/ lidar1_z/geoid12b/data/5019/mi2010_arra_4_county_se_ m5019_metadata.html.
For more information about this publication, contact

Director, Upper Midwest Water Science Center

U.S. Geological Survey

6520 Mercantile Way

Suite 5

Lansing, MI 48911

For additional information visit https://mi.water.usgs.gov/.

Publishing support provided by the

Lafayette, Madison, and Pembroke Publishing Service Centers 
